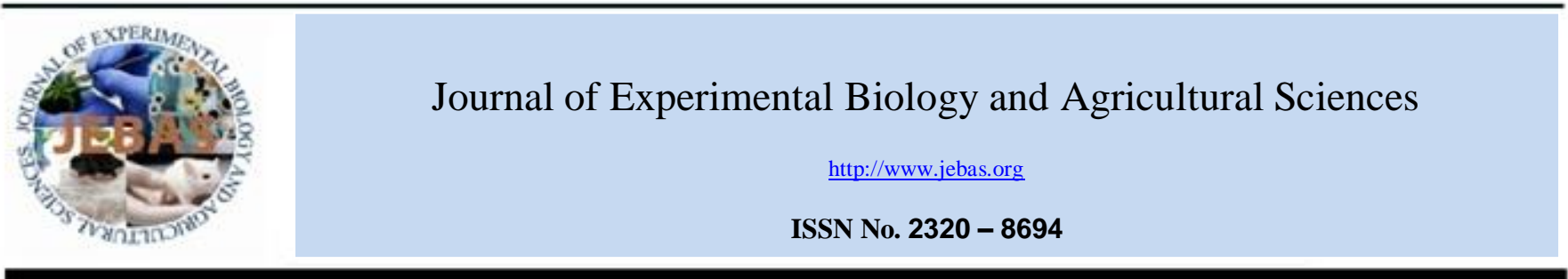

\title{
IMPACT OF FERTILIZER RECOMMENDATIONS BASED ON SOIL HEALTH CARD ON FERTILIZER CONSUMPTION, PRODUCTIVITY AND PROFITABILITY OF FARMERS
}

\author{
Anil Kumar ${ }^{1}$, Navjot Singh Brar ${ }^{1}$, Balwinder Kumar ${ }^{1}$, HK Verma ${ }^{2}$ \\ ${ }^{1}$ Farm Science Centre, Guru Angad Dev Veterinary \& Animal Sciences University, Tarn Taran, Punjab \\ ${ }^{2}$ Directorate of Extension Education, Guru Angad Dev Veterinary \& Animal Sciences University, Ludhiana
}

Received - March 27, 2019; Revision - May 14, 2019; Accepted - June 01, 2019

Available Online - June 10, 2019

DOI: http://dx.doi.org/10.18006/2019.7(3).249.254

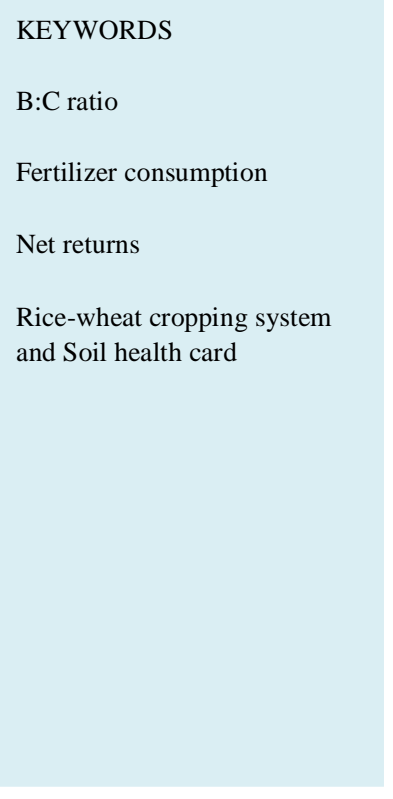

\begin{abstract}
The present study has analysed the impact of recommendations based on 'Soil Health Card' on fertilizer consumption, productivity and profitability of rice-wheat cropping system of the farmers of Tarn Taran district of Majha Region of Indian Punjab. Till 2014-15, farmers used to apply chemical fertilizers on the basis of their traditional knowledge without going for soil testing. They used to apply generally 372.3 and $156.3 \mathrm{~kg}$ urea and di-ammonium phosphate, respectively in wheat crop, whereas the usage of said fertilizers in paddy was to the extent of 371.0 and $62.5 \mathrm{~kg}$ per hectare, respectively. The total cost of cultivation of rice-wheat cropping system was $₹ 73,765 /$. The KVK approached the farmers and suggested them to apply fertilizers based on soil testing. After following soil test based fertilizer recommendations, fertilizer usage came down to $275 \mathrm{~kg}$ urea and $10 \mathrm{~kg} \mathrm{Zn} \mathrm{ha}^{-1}$ for paddy and $275 \mathrm{~kg}$ urea and $125 \mathrm{~kg} \mathrm{DAP} \mathrm{ha}^{-1}$ in case of wheat, indicating a net saving of ₹4,414/- per hectare per annum. Use of soil health card also improved soil health of the field resulting into additional crop yields with time. Continuous application of fertilizers based on soil test resulted in increased productivity of rice and wheat to the tune of 70.0 to 76.3 and 47.5 to $51.9 \mathrm{q} \mathrm{ha}^{-1}$, respectively. The respective net returns and $\mathrm{B}: \mathrm{C}$ ratio of rice-wheat cropping system has also increased significantly to ₹1,24,986 and 2.80 as compared to earlier net returns and B:C ratio of ₹1,04,264 and 2.41, respectively. Because of good profits, the farmers started motivating fellow farmers to adopt soil test based fertilizer application in different crops to get more crop productivity and sustaining soil health.
\end{abstract}

* Corresponding author

E-mail: anilkumarhpkv@gmail.com (Anil Kumar)

Peer review under responsibility of Journal of Experimental Biology and Agricultural Sciences.

Production and Hosting by Horizon Publisher India [HPI] (http://www.horizonpublisherindia.in/).

All rights reserved.
All the articles published by Journal of Experimental Biology and Agricultural Sciences are licensed under a Creative Commons Attribution-NonCommercial 4.0 International License Based on a work at www.jebas.org.

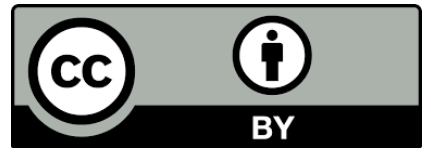




\section{Introduction}

The high use of chemical fertilizers in Indian agriculture since green revolution has increased the crop productivity many folds. However, their continuous, imbalanced and indiscriminate use has also produced several adverse impacts on soil environment leading to stagnated crop yields in past decades (Sebby, 2010; Kumar et al., 2016; Kumar et al., 2018). Intensive cropping system following indiscriminate use of high analysing fertilizers are further deteriorating soil health and inducing secondary and micronutrient deficiencies in soils, nutrient imbalance in soil and plants, causing environmental hazards and decrease in total factor productivity (Kumar et al., 2017). Microbial populations in soil ecosystem are affecting severely due to sole and indiscriminate usage of chemical fertilizer nutrients. Moreover, excessive fertilizer applications are also contaminating surface and underground water bodies especially by nitrate leaching (Pimentel, 1997). Above facts in turn, are inducing detrimental effects on environment, causing serious health hazards to human and animals. In India, in general, blanket fertilizer recommendations are followed for $\mathrm{N}, \mathrm{P}$ and $\mathrm{K}$ which rarely matches soil fertility need. Secondary and micro nutrients are often ignored in various cropping systems. Therefore, in present context, there is dire need to strictly follow integrated nutrient management system and supply of nutrients based on recommendations given in soil health card (SHC). Soil testing is a scientific method to evaluate soil fertility and suggesting balanced nutritional package involving organic and inorganic sources of nutrients to different crops and cropping systems (Chouhan et al., 2017). However, in past, the soil testing programme in India has unable to produce sensible impression on farming community due to lack of proper soil testing facilities especially micronutrient estimation, poor coverage, delay in dissemination of fertilizer recommendations among farmers, etc. (Biswas, 2002). Keeping in view the above facts, scientists are promoting integrated nutrient management (INM) concept i.e. balanced and judicious use of chemical fertilizers along with organic sources of nutrients (locally available organic manures, crop residues) and biofertilizers based on soil testing to sustain soil health and crop productivity on long term basis (Mahajan \& Gupta, 2009; Suri \& Kumar, 2011; Choudhary et al., 2014).

Fertilizer recommendations based on soil heath card has been proven as a great step towards sustainable crop production and soil health improvement vis-a-vis reduction in fertilizer dosage by farmers. Actually, soil health card provide detailed nutrients information and farmers get a well monitored report about their soil and they are guided by the experts to follow recommendations given in soil health card and improve soil health (Chouhan et al., 2017). Moreover, soil health card contains crop-wise nutrient recommendations (both organic \& inorganic sources) and corrective measures that helps farmer to obtain good yield potentials and better soil health. Hence, soil testing play a critical role in ensuring balanced and efficient use of fertilizers and sustaining soil health status and crop productivity. The soil testing facilities for the farmers in the district under study were far away and no guidance on said aspect was available to the farmers. The Krishi Vigyan Kendra (KVK), Tarn Taran has approached the farmers and motivated them for soil testing, after that KVK has issued soil health card to the farmers based on soil testing, where recommendations on nutrients application have been provided and now an attempt has been made to analyze the impact of fertilizer recommendations based on SHC on fertilizer consumption, productivity and profitability of farmers of the district.

\section{Materials and Methods}

\subsection{Study site}

Tarn Taran is one of the border districts, lies in the North West frontier of the Punjab, India. It lies between $31^{\circ} 7^{\prime}$ and $32^{\circ} 3^{\prime}$ North latitude and $74^{\circ} 29^{\prime}$ and $75^{\circ} 23^{\prime}$ in the East longitude. The climate of the district classified as tropical steppe, semi-arid and hot, which is mainly characterized by general dryness except for a short period during southwest monsoon season. During the summer months i.e. from April to June, weather is very hot and dry. The weather becomes humid and cloudy during July to September. The average rainfall of the district is $482.9 \mathrm{~mm}$.

\subsection{Technology transfer methodologies}

In order to achieve the objective of technology transfer on soil testing or soil test based fertilizer application and its adoption by the farmers of the region, different technology tools such as training programmes, demonstrations on soil sampling technique, on farm experimentation, etc. at different locations were carried out and used. The farmers were motivated for soil testing and many farmers follow up the soil testing. The samples so collected or received from farmers of the district were air dried, ground with wooden pestle and mortar, sieved through $2 \mathrm{~mm}$ sieve. The soil samples were analyzed for soil reaction $(\mathrm{pH})$, electrical conductivity (EC) and organic carbon (OC), available phosphorus $(\mathrm{P})$, potassium $(\mathrm{K})$ and micronutrients viz. zinc $(\mathrm{Zn})$, copper $(\mathrm{Cu})$, iron $(\mathrm{Fe})$ and manganese $(\mathrm{Mn})$ as per the standard procedures. Based on soil test results, the soil health cards were issued to the farmers and recommendations were provided for balanced fertilization and integrated nutrient management. Several farmers started following soil test based fertilizer application in rice-wheat cropping system, which subsequently reduced the dosage of chemical fertilizers in rice-wheat cropping system. 


\subsection{Impact study and sampling}

A thorough study was undertaken to assess the knowledge levels and knowledge upgradation of the farmers about soil testing. The study has analyzed the impact of fertilizer recommendations on fertilizer usage, crop yields, net returns, production and monetary efficiencies of the farmers' in rice-wheat cropping system. After 3 years of issuing soil health cards (i.e. soil health cards were issued during 2014-15 and impact study was conducted during 2017-18), data was collected randomly from 85 farmers $(n=85)$ of the district to whom soil health cards were issued. The data on fertilizer usage and crop yield before and after soil testing was recorded from said farmers (Table 1). Two major crops of the district i.e. rice and wheat was taken into consideration for the study.

\subsection{Economic analysis}

Gross returns $\left(₹\right.$ ha $\left.{ }^{-1}\right)=$ Yield $\left(\mathrm{q} \mathrm{ha}^{-1}\right) \times$ price of produce $\left(₹ \mathrm{~kg}^{-1}\right)$

Net returns $\left(₹\right.$ ha $\left.{ }^{-1}\right)=$ Gross returns $\left(₹ h^{-1}\right)-\operatorname{cost}$ of cultivation $\left(₹ h^{-1}\right)$

Benefit cost ratio $\quad=\frac{\text { Gross returns }\left(₹ \mathrm{ha}^{-1}\right)}{\text { Cost of culivation }\left(₹ a^{-1}\right)}$

(B:C ratio) $\quad=\frac{\text { Cost of cultivation }\left(₹ \mathrm{ha}^{-1}\right)}{\text { Cons }}$

The system productivity of rice and wheat crops under rice-wheat cropping system was computed by estimating wheat-equivalent-yield (WEY) by the formula suggested by Ahlawat \& Sharma (1993)

$\mathrm{WEY}=. \frac{\text { Yield of each crop }\left(\mathrm{t} \mathrm{ha}^{-1}\right) \times \text { Economic value of each crop }\left(₹ \mathrm{t}^{-1}\right)}{\text { Price of rice }\left(₹ \mathrm{t}^{-1}\right)}$

\subsection{Production and monetary efficiencies}

Production efficiency (PE) of rice-wheat cropping system $\left(\mathrm{kg} \mathrm{ha}^{-1}\right.$ $\mathrm{day}^{-1}$ ) was computed using following expression:

$\mathrm{PE}=\frac{\text { Total economic yield of rice-wheat cropping system as WEY }\left(\mathrm{kg} \mathrm{ha}^{-1}\right)}{365}$

System profitability in terms of monetary efficiency (ME) (₹ ha ${ }^{-1}$ day $^{-1}$ ) was calculated using following formula:

$\mathrm{ME}=\frac{\text { Total net returns of rice-wheat cropping system }\left(₹ \mathrm{ha}^{-1}\right)}{365}$

\section{Results and Discussion}

\subsection{Average general fertilization practices of the farmers}

As a whole farmers of district Tarn Taran usually apply 275-400 $\mathrm{kg}$ Urea, 125-175 kg Di-ammonium phosphate (DAP) $\mathrm{ha}^{-1}$ in wheat (Rabi season) and 275-325 kg urea ha ${ }^{-1}$ only in paddy/rice (Kharif season) (Kumar et al., 2017). Generally, most of the farmers supplements $\mathrm{N}$ and $\mathrm{P}$ nutrients through urea and DAP, respectively. However, some farmers use single super phosphate as a source of phosphorus. Potassium application is negligible in whole district (Kumar et al., 2017). Gypsum and zinc application before transplanting of paddy is usually done by most of the farmers, while few farmers practiced green manuring, besides very few farmers apply organic manure (FYM) in soil, if applied rates are very less than recommended ones. Moreover, none of the farmers applied biofertilizers. As a whole, most of the farmers apply excessive doses of nitrogenous and phosphatic fertilizers than the recommended ones and application of most of nutrients/amendments such as gypsum, zinc, sulphur without any deficiency and recommendations (Kumar et al., 2017).

Similarly, in current study, the farmers under consideration usually applied $372.3,156.3$ and $20 \mathrm{~kg}$ urea, DAP and others fertilizers (gypsum, MOP, $\mathrm{Zn}$, etc), respectively in wheat, whereas the use of above fertilizers in paddy were to the tune of 371.0, 62.5 and $10 \mathrm{~kg} \mathrm{ha}^{-1}$, respectively before soil testing (Table 1). However, the recommended doses of urea and DAP in wheat is 275 and $137.5 \mathrm{~kg} \mathrm{ha}^{-1}$ (Anonymous, 2017a). Similarly, only urea ( ) $275 \mathrm{~kg} \mathrm{ha}^{-1}$ has been recommended for paddy and there is no recommendation of DAP in paddy, if already applied in wheat (Anonymous, 2017b). Beside, above fertilizers zinc sulphate @ 16 $(33 \%)$ or $25(21 \%) \mathrm{kg} \mathrm{ha}^{-1}$ is recommended in paddy, if soils are deficient in said nutrient. If, recommended $\mathrm{Zn}$ has already applied in paddy crop then there is no need to apply $\mathrm{Zn}$ in wheat crop (Sadana et al., 2010). In current study, it was observed that farmers under study apply fertilizers much more than recommended ones in both the crops (Table 1).

\subsection{Impact of recommendations based on soil health card on fertilizer usage}

After providing recommendations as per soil test, a critical interpretation of the results was provided to the farmers. The farmers started the follow up of fertilizer recommendations given in soil health card. It was registered that the fertilizer application in wheat comes down to 275.0 from $372.3 \mathrm{~kg} \mathrm{ha}^{-1}$ with a net reduction of $97.3 \mathrm{~kg} \mathrm{ha}^{-1}$ in three years of soil testing (Table 2). Similarly, in case of paddy the

Table 1 Average general fertilization practices of the farmers before soil testing $\left(\mathrm{kg} \mathrm{ha}^{-1}\right)$

\begin{tabular}{|lcc|}
\hline \multicolumn{1}{|c}{ Input } & Wheat & Paddy \\
\hline Urea & 372.3 & 371.0 \\
\hline DAP & 156.3 & 62.5 \\
\hline Others * & 20 & 10 \\
*Gypsum, MOP, Zn, etc. & & $(n=85)$
\end{tabular}


fertilizer consumption reduced by $96.0 \mathrm{~kg} \mathrm{ha}^{-1}$, it comes down to $275.0 \mathrm{~kg} \mathrm{ha}^{-1}$ against earlier dose of $371.0 \mathrm{~kg} \mathrm{ha}^{-1}$ (Table 2). After soil testing and follow up of recommended fertilizer doses by farmers, the usage of other fertilizer doses such as gypsum and muriate of potash in case of wheat become almost negligible whereas, $\mathrm{Zn}$ application reported as such in paddy i.e. $10 \mathrm{~kg} \mathrm{ha}^{-1}$ in paddy (no difference before and after soil testing) (Table 2). After regular counselling with farmers, some farmers adopted soil test based fertilizer application. Farmers were guided to reduce fertilizer doses slowly from higher application rates to recommended ones, so that sudden decrease in crop yields may be avoided and a sustainable crop levels may be obtained. The farmers under study follow the instructions issued and reduce fertilizer doses slowly and doses reaches to recommended ones. Chouhan et al. (2017) also reported decrease in fertilizer consumption among farmers in paddy, soybean and maize after applying fertilizer based on soil test.

\subsection{Impact of recommendations based on soil health card on crop yields}

Keeping all other production factors constant, after applying soil test based fertilizer application a good positive response on crop yield of rice and wheat was recorded after three years of study (Table 3). The yield of wheat has been increased from 47.5 to $51.9 \mathrm{q} \mathrm{ha}^{-1}$ indicating an increase of $9.2 \%$. Similarly, paddy yield rose from 70.0 to $76.3 \mathrm{q}$ $\mathrm{ha}^{-1}$ with an increase of $9.0 \%$ following recommendations given in soil health card (Table 3). The increases in crop yields are obvious as soil testing provide the actual nutrient status in the soil and led to balanced fertilization. Prior soil tests helps in managing manure and fertilizer application. The balanced fertilization with time improves the soil physical, chemical and biological properties, which in turn provide favourable conditions for plant growth and higher crop yields.

The complex biological, physical and chemical interlink of healthy soil influenced plant water availability, prevent nutrient losses, improve microbial activities, increase nutrient cycling, etc. for food and fibre production (Al-Kaisi et al., 2014). The farmers having soils with low organic matter content were guided for the addition of organic manures, green manuring, etc. so that organic matter level in soils could be maintained to optimum levels. The benefits of healthy soil in sustaining crop production have also been witnessed by several workers (Shah et al., 2008; Kumar, 2012; Sarkar et al., 2016). Actually, healthy soils increase the capacity of crops to withstand weather variability and other factors. Moreover, increased uniformity of nutrient availability across the field optimizes responses to other management inputs too. All above factors lead to healthy soil and improve crop productivity. Increase in the yields of paddy, soybean and maize to the extent of $19.4,13.8$ and $3.0 \%$, respectively were also registered by Chouhan et al. (2017), while studying the impact of fertilizer recommendations based on soil health card among the farmers of Madhya Pradesh.

\subsection{Impact of recommendations based on soil health card on economics}

The impact of nutrient recommendations based on soil health card on economics of rice and wheat crops was studied. In case of wheat crop, the cost of cultivation reduced by ₹ $2,492 \mathrm{ha}^{-1}$ (Table 4). Similarly, production cost of rice has been decreased by ₹ 1,922 $\mathrm{ha}^{-1}$. The gross returns have been increased by ₹ 6,710 and 9,438 in case of wheat and rice, respectively following soil test based fertilizer application (Table 4). Net returns and benefit cost ratio have been increased to the extent of 25.4 and $17.0 \%$, respectively in case of wheat and 16.7 and $15.3 \%$, respectively in paddy after three years of study (Table 4).

After studying the individual returns from rice and wheat crops, system productivity and profitability of rice-wheat cropping system as a whole was also computed before and after soil testing (Table 5). The rice equivalent yield increased to the tune of $9.2 \%$

Table 2 Impact of recommendations based on soil health card on fertilizer usage $\left(\mathrm{kg} \mathrm{ha}^{-1}\right)$

\begin{tabular}{|c|c|c|c|c|c|c|}
\hline \multirow{2}{*}{ Input } & \multicolumn{3}{|c|}{ Wheat } & \multicolumn{3}{|c|}{ Paddy } \\
\hline & Before & After & Difference & Before & After & Difference \\
\hline Urea & 372.3 & 275.0 & -97.3 & 371.0 & 275.0 & -96.0 \\
\hline DAP & 156.3 & 125.0 & -31.3 & 62.5 & 00 & -62.5 \\
\hline Others & 20 & 00 & -20 & 10 & 10 & 00 \\
\hline
\end{tabular}

Table 3 Impact of recommendations based on soil health card on crop yield ( $\mathrm{q} \mathrm{ha}^{-1}$ )

\begin{tabular}{|c|c|c|c|c|}
\hline \multirow{2}{*}{ Crop } & \multicolumn{4}{|c|}{ Average yield $\left(\mathrm{q} \mathrm{ha}^{-1}\right)$} \\
\hline & Before & After & Difference & $\%$ increase \\
\hline Wheat & 47.5 & 51.9 & +4.4 & $9.2 \%$ \\
\hline Paddy & 70.0 & 76.3 & +6.3 & $9.0 \%$ \\
\hline
\end{tabular}

Journal of Experimental Biology and Agricultural Sciences http://www.jebas.org 
after following fertilizer recommendations of soil health card. The cost of production decreased by ₹ $4,414 \mathrm{ha}^{-1}$ (Table 5). In term of percentage the cost of cultivation decreased to the extent of $6.3 \%$. Similarly, net returns and benefit cost ratio of rice-wheat cropping system as a whole increased by 19.8 and $16.1 \%$, respectively (Table 5). Thus, indicating enhancement in productivity as well as profitability of farmers of the area.

Overall, reduction in the usage of costly fertilizer inputs by farmers has been registered with time that led to reduction in production cost and enhancement in profitability of the farmers. Above results are obvious as soil testing reduce the expenditure on costly input, which are otherwise unnecessarily added by farmers in the soil. Chouhan et al. (2017) also registered 54.8 and $13.3 \%$ higher net returns and $\mathrm{B}: \mathrm{C}$ ratio, respectively of paddy, while studying the impact of fertilizer recommendations based on soil health card on productivity and profitability of the farmers.

\subsection{Impact of recommendations based on soil health card on production and monetary efficiencies}

The production and monetary efficiencies of rice-wheat cropping system were increased by 9.2 and $19.5 \%$ after fertilizer application based on soil test (Table 6). The increases in crop yields resulted in higher production efficiency due to application of optimum or desired manure and fertilizer application to the crops based on prior soil test. Similarly, monetary efficiency was higher after following fertilizer recommendations because of reduced expenditures and more profit margins than earlier practices. Better crop yields owing to higher nutrient uptake and reduced expenditure on costly fertilizer inputs may be the possible reason for enhanced production and monetary efficiencies in current study. The higher production and monetary efficiencies following integrated nutrient package based on soil test were also reported by Kumar et al. (2015) in okra-pea cropping system.

Table 4 Impact of recommendations based on soil health card on economics of rice and wheat (₹ ha $\left.{ }^{-1}\right)$

\begin{tabular}{|c|c|c|c|c|c|c|}
\hline \multirow{2}{*}{ Variable } & \multicolumn{3}{|c|}{ Wheat } & \multicolumn{3}{|c|}{ Paddy } \\
\hline & Before & After & Benefit $(₹)$ & Before & After & Benefit (₹) \\
\hline Cost of cultivation (₹) & 36270 & 33778 & -2492 & 37495 & 35573 & -1922 \\
\hline Gross returns (₹) & 72438 & 79148 & +6710 & 105700 & 115138 & +9438 \\
\hline Net returns (₹) & 36168 & 45370 & +9202 & 68205 & 79565 & +11360 \\
\hline $\mathrm{B}: \mathrm{C}$ ratio & 2.00 & 2.34 & +0.34 & 2.81 & 3.24 & +0.43 \\
\hline
\end{tabular}

Table 5 Impact of recommendations based on soil health card on economics of rice-wheat cropping system (₹ ha $\left.{ }^{-1}\right)$

\begin{tabular}{|l|c|c|c|c|}
\hline \multicolumn{1}{|c|}{ Variable } & Before & After & Difference \\
\hline Wheat equivalent yield $\left(\mathrm{q} \mathrm{ha}^{-1}\right)$ & 117.9 & 128.7 & +10.8 \\
\hline Cost of cultivation (₹) & 73765 & 69351 & -4414 \\
\hline Gross returns (₹) & 178029 & 194337 & +16308 \\
\hline Net returns (₹) & 104264 & 124986 & +20722 \\
\hline B:C ratio & 2.41 & 2.80 & $19.8 \%$ \\
\hline
\end{tabular}

Table 6 Impact of recommendations based on soil health card on production and monetary efficiencies of rice-wheat cropping system

\begin{tabular}{|l|c|c|c|}
\multicolumn{1}{|c|}{ Parameter } & Before & \multicolumn{2}{c|}{ Rice-wheat cropping system } \\
Difference
\end{tabular}

Journal of Experimental Biology and Agricultural Sciences http://www.jebas.org 


\section{Conclusion}

After following fertilizer recommendations given in soil health card, farmers have saved ₹ 4,414 $\mathrm{ha}^{-1}$ annum $^{-1}$ (in rice-wheat cropping system). Soil health also improved resulting into additional crop yields with time. The net returns and B:C ratio increased to the tune of 19.8 and $16.1 \%$, respectively in ricewheat cropping system. The magnitude of increase in production and monetary efficiencies were 9.2 and $19.5 \%$, respectively. Thus, fertilizer recommendations based on SHC has found quite effective and beneficial to the farmers resulting in enhanced crop yield, income as well as improvement in soil health. These profits may further increase in future after continuous following of soil test based fertilizer application due to improved soil health and decreased fertilizer consumption.

\section{Acknowledgement}

The authors are highly thankful to ICAR-Agricultural Technology Application Research Institute, Zone I and Directorate of Extension Education, Guru Angad Dev Veterinary \& Animal Sciences University, Ludhiana for financial assistance and technical guidance, respectively for carrying out this study.

\section{Conflict of Interest}

The authors declare that there is no conflict of interest in this manuscript.

\section{References}

Ahlawat IPS, Sharma RP (1993) Agronomic Terminology ( $3^{\text {rd }}$ edn). Indian Society of Agronomy, New Delhi.

Al-Kaisi M, Douelle A, Kwaw-Mensah D (2014) Soil microaggregate and macroaggregate decay over time and soil carbon change as influenced by different tillage systems. Journal of Soil and Water Conservation 69: 574-580.

Anonymous (2017a) Package of practices for the crops of Punjab (Rabi 2017). Directorate of Extension Education, Punjab Agricultural University, Ludhiana (Punjab), 34: 1-17.

Anonymous (2017b) Package of practices for the crops of Punjab (Kharif 2017). Directorate of Extension Education, Punjab Agricultural University, Ludhiana (Punjab), 34: 1-15.

Biswas PP (2002) Soil testing at farmers door step. Fertilizer News 47: 21-24.

Choudhary AK, Rahi S, Kumar A (2014) Integrated Nutrient Management in Vegetable Crops. In: Advances in Field Crop Production (Ed. Rana et al), Venus Publishers, ISBN No. 978-9383168-08-8, pp 29-35.

Chouhan RS, Sharma HO, Rathi D, Niranjan HK (2017) Impact of soil health card scheme on farmers' income - A case study of Kharif crops in Madhya Pradesh. Agricultural Economics Research Review 30: 139-141.
Kumar A (2012) Phosphorus and rain harvested water economy through Vesicular Arbuscular Mycorrhizae (VAM) in okra pea sequence. Ph.D. Thesis submitted to the CSK HPKV, Palampur (HP).

Kumar A, Brar NS, Pal S, Singh P (2017) Available soil macro and micro-nutrients under rice wheat cropping system in District Tarn Taran of Punjab. Ecology, Environment and Conservation 23: 229-234.

Kumar A, Choudhary AK, Pooniya V, Suri VK, Singh U (2016) Soil Factors Associated with Micronutrient Acquisition in CropsBiofortification Perspective. In: Singh U, Praharaj C, Singh S, Singh N (Eds.) Biofortification of Food Crops. Springer, New Delhi. DOI 10.1007/978-81-322-2716-8_13.

Kumar A, Prakash B, Brar NS, Kumar B (2018) Potential of vermicompost for sustainable crop production and soil health improvement in different cropping systems. International Journal of Microbiology and Applied Sciences 7: 1042-1055.

Kumar A, Choudhary AK, Suri VK (2015) Influence of AMfungi and applied phosphorus on growth indices, production efficiency, phosphorus-use efficiency and fruit-succulence in okra (Abelmoschus esculentus)-pea (Pisum sativum) cropping system in an acid Alfisol. Indian Journal of Agricultural Sciences 85: 1030-1037.

Mahajan A, Gupta RD (2009) Role of INM in Sustainable Rice-Wheat Cropping System. In: Integrated Nutrient Management (INM) in a Sustainable Rice-Wheat Cropping System, Springer, Dordrecht.

Pimentel D (1997) Techniques for Reducing Pesticides: Environmental and Economic Benefits. Chichester, UK: John Wiley.

Sadana US, Manchanda JS, Khurana MPS, Dhaliwal SS, Singh H (2010) The Current Scenario and Efficient Management of Zinc, Iron, and Manganese Deficiencies. Better Crops- South Asia: 24-26.

Sarkar MIU, Rahman MM, Rahman GKMM, Nahe UA, Ahmed MN (2016) Soil Test Based Inorganic Fertilizer and Integrated Plant Nutrition System for Rice (Oryza sativa L.) Cultivation in Inceptisols of Bangladesh. The Agriculturists 14: $33-42$.

Sebby K (2010) The Green Revolution of the 1960's and Its Impact on Small Farmers in India. In: Environmental Studies Undergraduate Student Thesis. 10. http://digitalcommons.unl.edu/envstudtheses/10.

Shah AL, Islam MR, Haque MM, Ishaque M, Miah MAM (2008) Efficacy of major nutrients in rice production. Bangladesh Journal of Agricultural Research 33: 639-645.

Suri VK, Kumar A (2011) Potential of Integrated Nutrient Supply and Soil Health Improvement in Sustainable Cropping Systems of Indian Himalayas. In: Kumar A (Ed.) Sustainable Hill Agriculture: An overview, Agrobios (India), pp. 123-149. 